\title{
Applying a Transnational Approach to the Question of Irish Home Rule: Ireland, New Zealand and Home Rule
}

Une approche transnationale appliquée à la question du Home Rule irlandais :

l'Irlande, la Nouvelle-Zélande et le Home Rule

\section{Pauline Collombier-Lakeman}

\section{OpenEdition}

\section{Journals}

Electronic version

URL: http://journals.openedition.org/rfcb/3940

DOI: $10.4000 /$ rfcb.3940

ISSN: 2429-4373

Publisher

CRECIB - Centre de recherche et d'études en civilisation britannique

\section{Electronic reference}

Pauline Collombier-Lakeman, « Applying a Transnational Approach to the Question of Irish Home Rule: Ireland, New Zealand and Home Rule », Revue Française de Civilisation Britannique [Online], XXIV-2 | 2019, Online since 19 June 2019, connection on 09 July 2019. URL : http:// journals.openedition.org/rfcb/3940 ; DOI : 10.4000/rfcb.3940

This text was automatically generated on 9 July 2019.

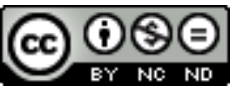

Revue française de civilisation britannique est mis à disposition selon les termes de la licence Creative Commons Attribution - Pas d'Utilisation Commerciale - Pas de Modification 4.0 International. 


\section{Applying a Transnational Approach to the Question of Irish Home Rule: Ireland, New Zealand and Home Rule}

Une approche transnationale appliquée à la question du Home Rule irlandais : l'Irlande, la Nouvelle-Zélande et le Home Rule

Pauline Collombier-Lakeman

\section{Introduction}

In an article entitled "Directions in historiography; our island story? Towards a transnational history of late modern Ireland", Enda Delaney denounces the role played by historians of post-Union Ireland in "construct[ing] an 'island story', with its central focus on domestic events." He contends that Irish emigration and the Irish diaspora, which have been studied ever since the 1940s and 1950s, have mostly been treated as a separate field, leading to the existence of two concurrent historiographies - "one covering the 'homeland', or domestic history, the other concerned with the 'diaspora', or migrant communities." Despite the publication of a growing number of comparative works on Irish emigrants across the world since the 1980s, Delaney urges historians to go further and advocates the writing of a "more inclusively global" history of Ireland based on the use of a "transnational analysis that investigates particular topics or themes across national boundaries." "The purpose of such a reading of history is to assess "how the connections with this diaspora shaped both the history of the homeland and that of receiving societies" in order to shape up the history of what he calls the "Irish world" or "Greater Ireland." Such a transnational approach is particularly relevant to examine Irish parliamentary nationalism since

[t]he home rule movement was the first broad-based nationalist movement to connect the diaspora in the U.S., Britain and Australia with a vigorous political campaign in Ireland. ${ }^{2}$ 
2 A transnational perspective allows not only to research nationalist organisations themselves but also to investigate "the exchange of ideas" and the views expressed by the Irish across the globe on issues such as imperialism. ${ }^{3}$

3 This paper will attempt to follow Delaney's suggestion. It stems from the idea that the Repeal movement launched by Daniel O'Connell coincided with the emergence of a form of long distance Irish nationalism favourable to a moderate scheme of parliamentary autonomy for Ireland. The great expansion of the Irish diaspora in the second half of the long $19^{\text {th }}$ century further strengthened the bonds between some of the Irish communities abroad and the Home Rule movement at home. To support this view, the study will limit itself to the case of one self-governing settlement colony - New Zealand. It may appear to be a surprising choice since New Zealand was never the first destination for Irish immigrants. However it must be kept in mind that it became a sought-after destination from the 1870s, notably because the policy of assisted immigration put into place by the NZ government of Julius Vogel. ${ }^{4}$ Despite the fact that the proportion of Irish-born migrants went from roughly $11 \%$ of the non-Maori population in 1878 to $5.6 \%$ in 1901 , the share of people of Irish descent among the New Zealand-born remained stable throughout the same period, at $20 \%$ in 1878 and $19 \%$ in $1901 .{ }^{5}$ In addition, no fewer than six fundraising tours took place between 1883 and $1911 .{ }^{6}$ This is all the more remarkable as the sea voyage to New Zealand took obviously longer and was more costly than the crossing to North America, a more frequent destination for the Irish. ${ }^{7}$ New Zealand was one of the destinations chosen by Irish Home Rulers not only because it included an Irish diaspora likely to back the cause but also because it had been granted a growing amount of self-governance from $1852 .{ }^{8}$

More precisely, we shall show that, despite being faced with persistent criticisms of the subject of Irish Home Rule, the successive Irish delegates met with growing success, as is attested by the sums of money collected for Irish Home Rule in New Zealand or by the establishment of Home Rule associations in New Zealand. The accounts of the tours made in the local and national press, the speeches delivered by the Irish delegates as well as the reactions of a number of New Zealand political figures also show that Irish Home Rulers and New Zealand politicians shared similar preoccupations - land, the changing nature and political organisation of the British Empire, and a growing sense of national consciousness. Some questions I will attempt to explore are how Irish Home Rulers tried to promote Irish legislative independence to New Zealand audiences, and what type of impact Irish Home Rule may have had on political debates in New Zealand. This will lead me to examine whether a link can be established between the growth of Irish constitutional nationalism and the emergence of colonial nationalism in New Zealand at the turn of the nineteenth and twentieth centuries.

\section{New Zealand as a source of increasing financial support for Irish Home Rule}

The first mission to Australasia in 1883 met with more hostility and resistance than the following tours, which were, to a certain extent, more successful. The Irish envoys in 1883 received what Richard P. Davis describes as a "chilling reception" in New Zealand, only managing to rally the support of the working class Irish but not of the lay and clerical elites. ${ }^{9}$ This was due to the circumstances in which the tour was organised. Even though 
Land League branches had been set up all over New Zealand following the Irish agrarian crisis of $1878-1879,{ }^{10}$ and even though New Zealand politician Robert Stout had declared himself in favour of Irish self-government in $1881,{ }^{11}$ the enthusiasm of the lay and clerical elites for the Irish cause had been short-lived. In the United Kingdom, the Liberals had attempted to crush the agrarian movement and although Charles Stewart Parnell had taken his distance from agrarian radicalism, ${ }^{12}$ the Phoenix Park murders of the newly appointed Irish Chief Secretary Lord Frederick Cavendish and his deputy Thomas H. Burke in May 1883 threw suspicions on the Irish nationalist movement and on the constitutional character of Irish demands. Irish envoys to New Zealand in 1883 were suspected of representing a movement condoning the use of violence against the British Crown and government. They also presented the potential risk of arousing dissensions in New Zealand, which explains the presence of hostile reactions in the New Zealand press as this example from the Waikato Times shows:

I was very sorry to hear of the arrival in New Zealand of two emissaries of the Irish Land League. We do not want them here, and it is a great pity that they have come. People of all creeds and all nationalities live here together in peace, and I very much regret the arrival of those emissaries, who are almost certain to sow discord. 13

6 Despite these difficult circumstances, William Redmond managed to collect $£ 1,400$ in the West Coast alone (including $£ 240$ at a meeting of 400 people in the town of Greymouth): this was, according to M. Campbell, far above the "target of $£ 1,000$ for all of New Zealand." ${ }_{14}$

7 Attitudes towards Irish Home Rule certainly changed after 1885 . The Irish nationalist party became organised and disciplined enough to win 86 seats in the 1885 British general elections and hold the balance of power at Westminster. The British Liberal leader William Ewart Gladstone had also converted to Irish Home Rule. An alliance between the Irish nationalists and the Gladstonian liberals could thus be established and the first Irish Home Rule Bill in the British House of Commons was introduced on 8 April 1886. This triggered a change in the way Irish tours in New Zealand were perceived. In 1889, John Dillon, Thomas Grattan Esmonde and John Deasy were, to quote one historian, “ rapturously received" and contrary to their predecessors, they benefited from the support major politicians and key figures of the Catholic hierarchy in New Zealand. As a result, they raised a total sum estimated at $£ 6,000 .{ }^{15}$ Joseph Devlin and John Donovan in 1906 and William Archer Redmond, Richard Hazleton with, again, John Donovan in 1911 also received the support of New Zealand politicians, high and low, as well as generous contributions: more than $£ 5,000$ in 1906 and $£ 10,000$ in $1911 .{ }^{16}$

8 The tours, meetings and the collection of funds would not have taken place without the existence of a network of Irish Home Rule organisations in New Zealand. The tour of the Redmond brothers may be regarded as successful in so far as it boosted local activism, with the creation of local branches of the Irish National League and even an Australasian federal council in charge of collecting funds and forwarding them to Ireland. According to Richard P. Davis,

National League branches sprang into fitful life in most of the country. (...) The West Coast, especially the Grey Valley which established a local federation holding annual joint meetings, was the most enthusiastic area in New Zealand. ${ }^{17}$

9 Later in the 1890s, there were at least two branches of the Irish National Federation - one in Wellington, one in Auckland, which actively campaigned for Irish Home Rule. R. Davis notes that after the reunification of the two warring factions within the Irish Parliamentary Party "no attempt was made to found new branches of the current Nationalist 
supporting organisation, the United Irish League"; however he briefly mentions the creation of one branch in Wellington before 1906, which survived until 1909 and acknowledges the activism of other societies in NZ such as the Hibernian Society ${ }^{18}$. The Redmond Papers in connection with New Zealand (four items) date back to the period 1902 \& 1907 and the detailed catalogue lists three correspondents as Edmond Carrigan, M. Bohan and P.M. Twomey, Irish National Federation, Wellington (1902, June 3).

Benedict Anderson argues that migrations and globalization have recently fostered the rise of a new nationalism which he identifies as "long distance nationalism" and which "no longer depends as it once [had] on territorial location in a home country." This new form of nationalism is visible in communities of exiled migrants who have retained ties with their homeland and attempt to remain involved in the national struggles at home. ${ }^{19}$ This theory has been further expanded by scholars Nina Glick Schiller and George Fouron in a study of the Haitian immigrant community in the United States. They consider the concept of long distance nationalism as

[...] a claim to membership in a political community that stretches beyond the territorial borders of a homeland", which "generates an emotional attachment that is strong enough to compel people to political action that ranges from displaying a home country flag to deciding to 'return' to fight and die in a land they may never have seen. ${ }^{20}$

11 The support received by Irish Home Rulers from New Zealand did not emanate only from the Irish diaspora alone, but it may be assumed that some amongst the New Zealanders of Irish descent may have been motivated by a form of long distance nationalism.

\section{New Zealand as a constitutional and political model for Irish Home Rule}

In order to obtain the support of the people of New Zealand - whether financial or moral - Irish Home Rule delegates first needed to convince their NZ audiences of the legitimacy of Irish claims or, to put it in the words of William Redmond as early as 1883,

to educate the public mind in this distant land upon Irish affairs, and to explain the true meaning of the claims made by the Irish Nation through its mouthpiece the National League. ${ }^{21}$

Members of the Irish Parliamentary Party were at heart pragmatists who knew perfectly well how to adapt their discourse to the audiences they were addressing. As Irish delegates were aware that New Zealand was deeply attached to the British Crown and Empire ${ }^{22}$ they used strategies that would convince New Zealanders of the moderation of Irish claims for self-government.

One of these strategies was to compare Irish Home Rule to the self-governing constitution New Zealand, as a colony, had obtained from Britain in 1852. As has been demonstrated by Thomas Mohr or Conor Neville, colonial precedents were far from rare in Irish or British discourse dealing with the question of Home Rule for Ireland. ${ }^{23}$ They were also a recurrent feature in the speeches delivered by the successive Irish delegates between 1883 and 1911. In 1883 for instance, William Redmond told his Kumara audience: "We ask just what you have in New Zealand -Home Rule. ... All we want is to have control over our own affairs, the same as you have in New Zealand." ${ }^{4}$ In 1889, Thomas Grattan Esmonde reasserted the same principle, though in a slightly more developed form: 
Here in New Zealand they had Home Rule, that is the management of their own affairs; and New South Wales or elsewhere had no right to interfere with them. They wanted the same liberty in Ireland, and were quite willing to leave all matters that affected the Imperial Parliament to the Imperial Parliament. (...) Home Rule did not mean that they should be to control the British Army or Navy, or be at liberty to raise troops, or volunteers; nor would they have the right to declare war against any other nation (...). They would not even have the power to levy custom tariffs to keep English goods out of the Irish market! But they would have the right to look after and control their own railways, the education of the people, and resources of the country generally. ${ }^{25}$

15 In a country that was still a British colony loyal to the Crown, Grattan Esmonde was careful to frame the Irish Home Rule project as a moderate demand. Self-government was a solution to obtain control of local affairs defined as railways, education or resources and clearly differentiated from Imperial issues, foreign affairs or trade, which were meant to stay under the control of Westminster. What was implicitly underlined was that the future Irish Parliament was to remain subordinate to the British Parliament, whose authority and supremacy were reasserted. In other words, Grattan Esmonde's discourse emphasised that Irish claims were limited, that Irish Home Rule was not a separatist scheme, and that the Irish would remain loyal despite their aspirations to more autonomy. This was a direct response to the enemies of Irish Home Rule, who regarded it as a threat likely to lead to the dismemberment of the British Empire. ${ }^{26}$ Irish delegates to New Zealand argued instead that Ireland's legislative autonomy was perfectly compatible with the maintenance of the country within an imperial frame. Such ideas were perfectly adapted to audiences in New Zealand where imperialism and nationalism were regarded as perfectly compatible and seemed to go hand in hand. ${ }^{27}$

16 In 1895, Michael Davitt was just as cautious as Grattan Esmonde in his choice of words when he gave his definition of Home Rule. It was

simply what the people had in New Zealand, in Victoria, in New South Wales, in Queensland, in Western Australia, and in Tasmania - that and nothing more", and as a result, "[t]here was, therefore, in the Home Rule movement nothing new, revolutionary or untried. It was eminently constitutional and, in the best and biggest sense of the word, conservative (...)..$^{28}$

This choice of words is particularly interesting considering the fact that Davitt was an exFenian and spent a very limited amount of time working as an MP in the British Parliament because - in the words of historian Carla King - he "deeply disliked Westminster". ${ }^{29}$ In 1906 the newly elected Home Rule MP for West Belfast Joseph Devlin did not explain in great details to his Invercargill audience what Home Rule for Ireland entailed; he simply noted that "the people of New Zealand were (...) greatly blessed in the democratic form of Government which they enjoyed", adding that "it was for such a form of government that the Home Rule Party was striving." 30 Again in 1911 his colleague Richard Hazleton stressed that "they in Ireland asked for was the principle that they in New Zealand possessed - the right to manage and control their own domestic and internal affairs." 31

What is striking in all these quotes is that Irish delegates gave fairly vague definitions of what Home Rule for Ireland meant to them beyond establishing the fact that New Zealand might represent a colonial precedent for it. It may be because, at the time, there was no uniform or consistent definition of Home Rule, which could be referred to either as a form of "decentralisation" or a scheme of "local self-government", "national self-government" or "federal union." ${ }^{2}$ The comparison with New Zealand may also have been more of a symbol and a pragmatic ploy than a true aspiration. Even though Irish Home Rule was 
inspired by the political autonomy given to certain British colonies, especially Canada, ${ }^{33}$ neither the British Liberals nor the Irish nationalist MPs actually contemplated putting Ireland in the position of a self-governing colony. Ireland was to have its own Parliament but it was to retain a certain number of MPs in Westminster, which was not the case of any independent Crown colony. ${ }^{34} \mathrm{John}$ Redmond made it very clear that being selfgoverning under a scheme of Home Rule or as a crown colony were two different situations: excluding Irish MPs from Westminster would mean that Ireland would be governed "as a Crown Colony", which was in his view "an alternative to Home Rule." 35

The multiples references to the New Zealand political system as a potential model for Ireland show nonetheless that Irish Home Rule delegates believed lessons could be learned from the Antipodes beyond the issue of self-government. In his account of the tour he did in 1895, Michael Davitt noted that New Zealand presented a number of features that he deemed worthy of admiration and even worthy of copying: women had the right to vote, even if they did not have the right to be elected to Parliament; there was an "enlightened body of Labour laws" which he deemed a "splendid code of remedial laws" that would be "valuable [to] every student of Labour legislation"; land laws had been passed,

rightly helping, by the direct encouragement of the state, a transition from the system of private property in land to that of state tenancy under the most favourable terms and conditions possible for labour. ${ }^{36}$

In 1911, Richard Hazleton also expressed admiration at the Labour reforms New Zealand had undergone and praised its police system. For Hazleton as for Davitt, the future politicians of Ireland could benefit from experiences made in New Zealand, especially in the field of municipal government. ${ }^{37}$ During the same tour, William Archer Redmond wrote to the Minister of Railways, John Andrew Millar, to praise the "management and conduct of State railways", adding that "one of the first reforms [Irish nationalists] hop[ed] to bring about under Home Rule [would] be the nationalisation of the Irish railways." 38

21 Historian Keith Sinclair remarks that New Zealanders "were proud of their political and economic achievements; and of their success in establishing themselves in a new land." David Hamer further notes that the New Zealand Liberals "associated their reforms with the concept of New Zealand showing the way to the rest of the world, [which] proved very appealing to New Zealanders (...)." ${ }^{39}$ The press, together with some of the local figures who welcomed the Irish delegates, did express the belief that New Zealand could serve as a model and teach the Irish about constitutional government and reforms. ${ }^{40}$ At the same time, the sources also show that Ireland was a possible source of inspiration, both for the Empire and New Zealand itself.

\section{The Irish Home Rule Struggle as a trigger to political debates in New Zealand}

The Anglo-Irish issue appears also to have helped raise the issues of Imperial federation and of a growing separate national consciousness in New Zealand.

\section{Imperial federation}

Because Irish Home Rule was a form of legislative autonomy that was meant to work within the imperial framework, it was seen by some as a first step towards a federation 
that would go beyond the borders of the United Kingdom and include all the colonies of the British Empire, with local independent parliaments in each self-governing entity and an Imperial Parliament in Westminster representing all these autonomous colonies ${ }^{41}$. From the 1850s until the First World War, leading political figures in New Zealand proved particularly concerned with the question of Imperial Federation: Julius Vogel, Sir George Grey, and even

each premier in succession from 1883-1912, Atkinson, Stout, Balance, Seddon, Ward, [who] may be cited as offering, on some occasion or another, some measure of support to [that] ideal (..... ${ }^{42}$

Three men in particular stood out for their staunch defence of the implementation of a specific body supervising imperial affairs and a greater say for New Zealand in imperial matters: New Zealand Premier Richard John Seddon, his Minister of Labour and Education and later to become Agent-General and first High Commissioner for New Zealand, William Pember Reeves, and Sir Joseph Ward, Seddon's successor to the New Zealand Premiership.

These men, and a few others, actually used the struggles of the Irish nationalists and the meetings organised in their honour as opportunities not only to advocate Home Rule but also to plead for the setting up of an imperial federation that would include, among other nations, Ireland and New Zealand. In 1889, a few months prior to the arrival of John Dillon, Thomas Grattan Esmonde and John Deasy, William Pember Reeves attended a public meeting at the Oddfellows' Hall in Christchurch in support of Charles Stewart Parnell, who had been the target of a smear campaign in the London Times and was being investigated for his connection with radical nationalists by a Special Commission. Pember Reeves moved a resolution stating that:

The success or failure of Mr Gladstone and the Liberal Party (and in that Liberal party you must allow me now to include Mr Parnell and his friends) is a matter of the deepest interest and greatest moment not only to Ireland, to England and to Scotland, but to everyone of that vast aggregation of states, of which Queen Victoria is the head. (Cheers). Surely it is vain to deny that the granting or denial of Home Rule will have a very direct influence on the hurrying on or delaying of Imperial federation. (...) If in the future the scattered lands which make up the British Empire are to be drawn more closely together, the active co-operation of the Irish element will absolutely be needful (Applause). ${ }^{43}$

During the Irish Home Rule tour of 1889 proper, New Zealand Premier Harry Atkinson, former New Zealand Governor and Premier Sir George Grey, and New Zealand Liberals John Ballance, Thomas Young Duncan and Robert Stout all pleaded for Home Rule as leading to Imperial federation. ${ }^{44}$ The latter asserted during the Dunedin Irish meeting that "Home Rule ... would be the prelude to federation," while Atkinson, in a letter read at the Wellington meeting, declared himself "fully convinced" that Home Rule, on which he looked upon favourably, would represent "the first great step towards the federation of the British Empire in lasting form." ${ }^{45}$ That imperial federation would have been discussed in connection with Irish Home Rule in such a way in 1889 is not surprising in so far as both questions aroused vivid interest at the time: the first Irish Home Rule Bill had been debated in 1886 and interest in imperial federation had been revived thanks to the creation of Imperial Federation League in $1884 .^{46}$

Between 1897 and 1911, New Zealand took part in the Colonial Conferences organised in Britain and New Zealand representatives were at the forefront of the campaign asking for a reform of imperial institutions and the establishment of an imperial council. ${ }^{47}$ This idea of a Council of Empire was again taken up during the Irish Home Rule missions of the 
early twentieth century. In 1907, a year during which an Imperial Conference took place and New Zealand was also granted Dominion status, Martin Kennedy, as one of local organisers of the Irish tour, moved a resolution during the meeting organised in Wellington, which was "carried with extraordinary enthusiasm" and predicted that: "(...) an advisory body - a Council of Empire - would be an imperative necessity for the great force of Home Rule not only for Ireland but for every constituent part of the British Empire." More importantly the New Zealand Premier Joseph Ward, who was to defend the idea of an Imperial Council four years later at another Imperial Conference, emphasised that

the solidarity of the Empire, the knitting together of every part of it was essential for its preservation from the attacks of dominant powers, which did not see eye to eye with England, Scotland, or Ireland. ${ }^{48}$

However, even though there were leading New Zealanders advocating imperial federation, there was no widespread enthusiasm in the country for it. The lower house of the New Zealand Parliament or House of Representatives as well as the general public did not express great interest in or support for the idea of imperial federation. Even politicians that did advocate the federal cause could be at times inconsistent: such was the case of John Balance or Sir George Grey for example. As is underlined by Keith Sinclair, "in general the New Zealand politicians who favoured imperial federation were exceedingly vague on the constitutional issues involved." ${ }^{49}$ In that regard, New Zealand political elites shared a common point with their Irish nationalist colleagues. Even though the latter also expressed sympathy for the idea of Imperial federation, ${ }^{50}$ they did so in vague and general terms and first and foremost gave priority to Irish Home Rule. ${ }^{51}$ Just like Irish nationalist MPs, New Zealand Liberal leaders were pragmatists with regard to the question of the imperial connection and the issue of imperial federation. ${ }^{52}$ To quote David Hamer, "[i]ts politicians were calculatingly 'imperial', using the opportunities the imperial connections afforded (...)."

\section{A growing national consciousness in New Zealand?}

In New Zealand, imperialism was regarded as compatible with patriotism, as is underlined by Keith Sinclair:

New Zealand imperialism under the liberals was no evidence of the absence of nationalism but was itself an expression of an emergent New Zealand nationalism. (...) Seddon and his followers were nationalists little influenced by the modern doctrines of nationalism but devoted to what they regarded as New Zealand's interests. (...) Those attitudes or sentiments which are usually called, in this connection, 'imperialism' and 'nationalism' did not to them seem incompatible. Their tariff policy was evidence of 'colonial nationalism', their defence policy of 'imperialism'; their impatience with the residual authority of the Colonial office was 'nationalist', their dreams of a council 'imperialist'. ${ }^{53}$

Sinclair suggests the existence of multiple yet compatible identities for New Zealanders, including a form of "nationalism". In 1889 John Dillon was able to witness this increasing sense of national consciousness. He noted in a speech delivered in Dunedin:

Since I came to the colonies I have noticed with unbounded pleasure the growth of a national spirit amongst the young men of the colonies, and, noticing that feeling growing up, it does not surprise me that they should sympathise with the aspirations and struggles of the people of Ireland. (...) And I will say further, that in my judgement no community of people are in a fair way to achieve the highest development of their social life unless they are permeated and animated by this 
national spirit, which is at the root of our struggle in Ireland, and which is, I

believe, growing up strong, youthful, and vigorous in these Australian colonies. ${ }^{54}$

31 nationalism and imperialism or attachment to the union with Britain and the empire. As a result, what actually had developed under British domination in both countries were varied forms of loyalism and layered and complex identities. Some New Zealanders were aware of that, as is shown for instance by this revealing remark from a participant to a debate dealing with New Zealand nationality at the Royal Colonial Institute in London in 1911:

New Zealand as a country had a capacity for assimilation. While English, Scotch, and Irish, had retained some of their original sense of separate nationality, yet the blending process was going on, and over these separate nationalities there was being superimposed a sense of New Zealand nationality. (...) [T]here was a double patriotism. Originally there were the local and New Zealand patriotisms, and now they found a New Zealand patriotism, blended with, but without the least weakening or tending do disintegrate, the old sentiment of nationality as Britishers. ${ }^{55}$

While this quote only defines New Zealand identity as predominantly white and British, it also interestingly assimilates the Irish to an immigrant population of British stock despite the fact that some of the Irish settlers were Catholic. Religious dissensions are omitted to focus instead on the relationship to the home country and the host country and suggest an allegiance to both. For John Redmond the Irish nation necessarily included all Irishmen and women whatever their religious affiliations. At the same time, he imagined Ireland both as a nation and a part of the British Empire that had contributed to its expansion and power. As a result, he stressed in front of the Commons that he believed the Irish people capable of combining an "Imperial patriotism" with a "local patriotism." 56

Several factors and events may account for this growing sense of national identity in New Zealand. First in 1886, the majority of the white population was New Zealand born; a great majority were below the age of 20 but as years passed the proportion of native-born white New Zealanders slowly but surely came to grow. ${ }^{57}$ The implementation of better means of communication with post-offices, telegraphs and railways helped the setting up of many national and no longer provincial or local organisations. ${ }^{58}$ Concerns with defining New Zealand identity were expressed in the press, in political debates, and in the works of the first locally-born poets. ${ }^{59}$ These concerns emerged particularly during the debates that surrounded the decision for New Zealand to join the Australian federation. Even though New Zealand did send representatives to most of the intercolonial conferences that discussed the Australian federation issue, ${ }^{60}$ and even though the strength of the New Zealand movement favourable to federation with Australia is still a matter of debate and needs to be properly assessed ${ }^{61}$ some historians have interpreted New Zealand's decision not to join the Australian federation as a proof that New Zealanders felt fundamentally different from Australians and that a sense of a separate national identity was already present in New Zealand. ${ }^{62}$

Throughout the debates on the question of federation with Australia, politicians argued against federation by underlining differences - differences in history, climate or geography and so differences in national character. ${ }^{63}$ Slogans warning against any sacrifice of political independence were put forward, such as "New Zealand should be a

Revue Française de Civilisation Britannique, XXIV-2 | 2019 
country for New Zealanders." ${ }^{44}$ Interestingly enough, similar slogans were used by the opponents of Irish Home Rule against the Irish missions of 1883 or 1889:

We ought, when we settle here, to forget any differences that there were in the old world, and to consider ourselves all New Zealanders, and to strive for the prosperity of ourselves and our adopted country; still my cry is New Zealand for the New Zealanders. ${ }^{65}$

This example of hostile reaction to the importation of Irish issues in New Zealand show that Irish Home Rule could give way to expressions of extreme loyalty to the new country of adoption. Confrontations with countries that were deemed as essentially different whether it was Australia or Ireland - gave rise among certain groups in the New Zealand population to a sense that they possessed a distinct and separate identity.

The supporters of the Irish cause in New Zealand also viewed the struggle of the Irish as potentially inspiring for the new generations of New Zealanders. As early as 1883, the Wellington Evening Post, a newspaper favourable to Irish Home Rule, defended the cause in terms that betrayed dissatisfaction with British imperial policy and a strong resolve to preserve New Zealand's independence:

Colonists, and New Zealand colonists in particular, cannot help putting the case to themselves, and considering how they would like their entire domestic legislation to be conducted by the Imperial Parliament, which has always exhibited such signal incapacity to deal with their affairs or even to understand them. (...) We should not like it at all. Already we have suffered enough indirectly through the interference, in our special affairs, of doctrinaires such as Sir Arthur Gordon or fanatical philoMaori Exeter Hall orators. We colonists of New Zealand know too well what would be the effect on ourselves if the Imperial Parliament, influenced as it so largely is by these well-meaning but mistaken people, had absolute control of our affairs. ${ }^{66}$

This quote seems to indicate that Ireland and New Zealand shared a similar distrust of central authorities. Other parallels were sometimes made between the two countries. In early 1889, a few months before the arrival of John Dillon and his colleagues, a plea for Irish Home Rule by John Ballance included an interesting parallel between Ireland's and New Zealand's respective pasts:

Have we forgotten our own struggles say thirty or forty years ago, when certain men, leaders, and men of advanced opinions fought for the right of constitutional government and obtained it, and have we gone so far back as to believe that this step was wrong, and that England had lost any of its power, strength, or glory in consequence of these colonies having the right of self-government? ${ }^{67}$

What is interesting here is Ballance's appeal to history and to memories common to all white New Zealanders to justify Irish claims. Before 1889 scholars like John Stuart Mill or Ernest Renan had underlined that a nation could only exist if it possessed "a national history and consequent community of recollections; collective pride and humiliation, pleasure and regret, connected with the same incidents of the past." ${ }^{68}$ What can be seen with the words of Ballance is that the Anglo-Irish question, together with other issues, led the white elites in New Zealand to turn important historical events into myths of foundation that would be significant for a country with a growing sense of national consciousness. As a white colony of settlement, New Zealand was still in need of its own founding moments or heroes. In that regard again, Ireland was a source of inspiration; in Oamaru in 1895, Mayor William Waddell welcomed Michael Davitt with standard words of compliment. However, they might reveal that white New Zealand aspired to become a nation with heroes similar to those of Ireland: 
Michael Davitt was a patriot, and they were scarce. His visit would perhaps inspire some among them, especially the youth of the Colony, with that spirit of patriotism which does so much to make a nation. (Applause). ${ }^{69}$

\section{Conclusion}

In a recent study examining the role of Irish migrants to the United States, Alan O'Day established that the Irish diaspora had three "broad functions" for the Irish nationalist leaders, namely:

(...) to gather the finance necessary for the national struggle at home; to muster moral support behind Ireland's claims; and to exert pressure on the policy-makers in the United States to use their resources in ways designed to injure British interests if [Britain] did not accede to Irish self-government. ${ }^{70}$

Our brief analysis of Irish Home Rule missions to New Zealand as seen by the local and national press in the colony shows that such a definition can apply to the New Zealand case. Fundraising tours in New Zealand did provide money that proved vital for the Irish Parliamentary Party; the interest and enthusiasm aroused was also instrumentalised in an attempt to coerce the British government and public opinion into the granting of selfgovernment to Ireland. But it seems that the role of Irish immigrant communities and the relationship between Irish and foreign political elites was more elaborate and complex. As this paper has attempted to show, Irish fundraising tours in New Zealand were opportunities for mutual exchanges and learning experiences between the two countries. Both were both under British domination. However, New Zealand had obtained selfgovernment as well as Dominion status; and like Canada or Australia, it was an example that legislative autonomy was compatible with strong links with Britain and the maintenance of the British Empire. Contrary to Ireland, where nationalism was no new phenomenon and where the Irish political elite had long claimed that Ireland had a distinct identity, New Zealand was perhaps not yet a nation of its own; nevertheless, national consciousness was emerging and the various visits of Irish nationalist MPs served as opportunities to raise questions about New Zealand's political future and identity.

\section{BIBLIOGRAPHY}

\section{Primary sources}

National Library of Ireland, Dublin, Ms 697.

Grey River Argus

Inangahua Times,

New Zealand Mail 
New Zealand Tablet

New Zealand Truth

North Otago Times

Otago Witness

Poverty Bay Herald

Star

Te Aroha News

Wanganui Herald

Wellington Evening Post

New Zealand Official Year-Book 1902, Government Printer, Wellington.

Davitt, Michael. Life and Progress in Australasia (London, Methuen \& Co., 1898).

Davitt, Michael. The Fall of Feudalism in Ireland, or The Story of the Land League Revolution (London, Harpers \& Brothers, 1904).

McCarthy, Justin “The Common Sense of Home Rule”, The Nineteenth Review, (march 1880), pp. 406-21.

Lord Salisbury, "Disintegration. Speeches of the Right Hon. W. E. Forster, M. P., at Devonport and Stonehouse", The Quarterly Review, CLVI, 312 (October 1883), pp. 559-95.

\section{Secondary sources}

“Te Ara The Encyclopedia of New Zealand". https://teara.govt.nz/en.

Anderson, Benedict, The Spectre of Comparisons: Nationalism, Southeast Asia and the World (London: Verso, 1998).

Anderson, Benedict, "Western Nationalism And Eastern Nationalism”, New Left Review (May-June 2001), in https://newleftreview.org/II/9/benedict-anderson-western-nationalism-and-easternnationalism [17 March 2017]).

Belich, James, Paradise Reforged: A History of New Zealanders from the 1880s to the Year 2000 (Auckland, Penguin, 2001).

Burgess, Michael, The British Tradition of Federalism (London, Leicester University Press, 1995).

Campbell, Malcolm, "John Redmond and the Irish National League of Australia and New Zealand, 1883”, History, LXXXVI, n²83 (2001), pp. 348-362.

Campbell, Malcolm, "Irish Immigrants in the Pacific World", in Laurence M. Geary \& Andrew J. McCarthy (eds.), Ireland, Australia \& New Zealand: History, Politics and Culture (Dublin, Irish Academic Press, 2008), pp. 3-13.

Curtis, Lionel. P, Coercion and Conciliation in Ireland, 1880-1892: A Study in Conservative Unionism, (Princeton, Princeton Books, 1963).

Davis, Richard P., Irish Issues in New Zealand Politics (Dunedin, University of Otago Press, 1974).

Delaney, Enda, "Directions in historiography; our island story? Towards a transnational history of late modern Ireland", Irish Historical Studies, XXXVII, no. 148 (November 2011), pp. 599-621. 
Hearn, Terry, “Irish Migration to New Zealand to 1915”, in Lyndon Fraser (ed.), A Distant Shore, Irish Migration and New Zealand Settlement (Dunedin, University of Otago Press, 2000), pp. 55-74.

Glick Schiller Nina \& George Fouron. George Woke Up Laughing: Long Distance Nationalism and the Search for Home (Durham: Duke University Press, 2001).

King, Carla, Michael Davitt (Dundalk, Dundalgan Press, 1999).

Lyons, Francis Stewart Leland, Charles Stewart Parnell (London, Collins, 1977).

McIntyre, W. David, "Imperialism and Nationalism”, in Geoffrey W. Rice (ed.), Oxford History of New Zealand (Auckland \& Oxford, Oxford University Press, 1992), pp. 337-350.

Martin, Ged, "New Zealand and Australian Federation", http://www.gedmartin.net/publishedwork-mainmenu-11/153-australia-new-zealand-and-federation-1883-1901 [5 September 2018].

Mohr, Thomas, "The Impact of Canadian Confederation in Ireland," in M. Martel, J. Krikorian \& A. Shubert (eds.). Globalizing Confederation - Canada and the World in 1867 (Toronto, University of Toronto Press, 2017), pp. 178-93.

Neville, Conor, “Imperial Precedents in the Home Rule Debates, 1867-1914”, MLitt., NUI Maynooth, 2011.

O'Day, Alan, "Irish Nationalism and Anglo-American Relations in the Later Nineteenth and Early Twentieth Century", in Fred. M. Leventhal \& Roland Quinault (eds.), Anglo-American Attitudes: from Revolution to Partnership (Aldershot, Algate, 2000), pp. 168-194

Renan, Ernest, E. Renan, “Qu'est-ce qu'une nation”, Sorbonne, 11 March 1882, in Joël Roman (ed.), Qu'est-ce qu'une nation ? et autres essais politiques, (Paris, Pocket, 1992), pp. 37-56.

Robson (ed.), John Mercel, Collected Works of John Stuart Mill, vol. XIX, Essays on Politics and Society (London, Routledge \& Kegan Paul, 1977).

Sinclair, Keith, Imperial Federation, A Study of New Zealand Policy and Opinion 1880-1914 (University of London, The Athlone Press, 1955).

Sinclair, Keith, A History of New Zealand [1959] (London, Penguin, 2000).

Sinclair, Keith, "The beginnings of colonial nationalism: Richard Jebb in New Zealand, 1899", in John Eddy \& Deryck Schreuder (eds.), The Rise of Colonial Nationalism, Australia, New Zealand, Canada and South Africa First Assert Their Nationalities, 1880-1914, Sydney, Allen \& Unwin, 1988, pp. 111-130. Sweetman, Rory, “ 'The Importance of Being Irish', Hibernianism in New Zealand, 1869-1969”, in Lyndon Fraser (ed.), A Distant Shore, Irish Migration and New Zealand Settlement (Dunedin, University of Otago Press, 2000), pp. 135-54.

Tapp, Edwin J. \& Miles Fairburn, “New Zealand and Australian Federation, 1883-1901: Another View”, New Zealand Journal of History, vol. 4 (1970), pp. 138-159

\section{NOTES}

1. E. Delaney, "Directions in historiography; our island story? Towards a transnational history of late modern Ireland", Irish Historical Studies, xxxvii, no. 148 (November 2011), pp. 599-600, 602 \& 619.

2. E. Delaney, "Directions in historiography", p. 612.

3. Ibid., p. 618. 
4. Irish immigration reached a peak in the early 1880s; then it declined, especially after 1891 and only started to increase again after 1906: see Terry Hearn, "Irish Migration to New Zealand to 1915", in Lyndon Fraser (ed.), A Distant Shore, Irish Migration and New Zealand Settlement (Dunedin, University of Otago Press, 2000), p. 68.

5. Malcolm Campbell, "Irish Immigrants in the Pacific World", in Laurence M. Geary \& Andrew J. McCarthy (eds.), Ireland, Australia \& New Zealand: History, Politics and Culture (Dublin, Irish Academic Press, 2008), p. 5 \& “Te Ara - The Encyplopedia of New Zealand", http:// www.teara.govt.nz/en/1966/nationalgroups/1 [12 September 2018].

6. The first one involved John and William Redmond as well as John W. Walshe, who toured throughout New Zealand between September and November 1883. Six years later, John Dillon, Sir Thomas Grattan Esmonde and John Deasy toured New Zealand from November to December 1889. They were followed by Michael Davitt, who travelled through New Zealand in November and December 1895, Joseph Devlin and John. T. Donovan, who toured the country between December 1906 and February 1907 and Richard Z. Hazleton, William A. Redmond and John. T Donovan, who stayed there between May and July 1911. A smaller mission also took place in 1891, when the MP J. R. Cox visited New Zealand in September and October on behalf of the anti-Parnellite section of the Irish Parliamentary Party.

These tours are examined in Richard P. Davis, Irish Issues in New Zealand Politics (Dunedin, University of Otago Press, 1974); Rory Sweetman, “ 'The Importance of Being Irish', Hibernianism in New Zealand, 1869-1969”, in Lyndon Fraser (ed.), A Distant Shore, pp. 135-54 \& Malcolm Campbell, "John Redmond and the Irish National League of Australia and New Zealand, 1883", History, LXXXVI, n²83 (2001), pp. 348-362.

7. The voyage To New Zealand lasted between 75 and 120 days and cost $£ 15$ against 10 days and $£ 4$ for the crossing to America ("Te Ara - The Encyplopedia of New Zealand", https:// teara.govt.nz/en/the-voyage-out/page-1 [29 November 2018]).

8. In 1852 the British Parliament voted the New Zealand Constitution Act, which granted selfgovernance to the territory. In 1857, the New Zealand Constitution Act was amended, granting New Zealand even more autonomy, although the Governor and the British Parliament kept control over issues such as foreign relations and Maori affairs. In 1901 New Zealand made the choice not to join the Australian Federation. In 1907 it was granted Dominion status by Britain.

9. Richard P. Davis, Irish Issues in New Zealand Politics, pp. 102-104; Rory Sweetman, "Hibernianism in New Zealand, 1869-1969", pp. 140-141 \& Malcolm Campbell, 'John Redmond and the Irish National League', p. 357.

10. Richard P. Davis, Irish Issues in New Zealand Politics, p. 100.

11. Robert Stout, The Irish Question and its Lessons for Colonists, 1881.

12. At the end of April 1882, Charles Stewart Parnell transmitted a letter to William Gladstone via William O'Shea, in which he envisaged the possibility to "co-operate cordially for the future with the Liberal Party in forwarding Liberal principles and measures of general reform." (Letter of Charles Stewart Parnell to William O'Shea, 28 April 1882, in Francis Stewart Leland Lyons, Charles Stewart Parnell (London, Collins, 1977), pp. 200-1.)

13. Waikato Times, 18 September 1883, p. 2. See also the Otago Daily Times as quoted by the Grey River Argus (Grey River Argus, 11 October 1883 p. 2).

14. Malcolm Campbell, "John Redmond and the Irish National League of Australia and New Zealand, 1883", p. 358.

The sum that was collected in New Zealand in 1883 exceeded expectations at the time but was certainly nothing in comparison to what Irish nationalists had been able to obtain a few years before during the Land War thanks to Parnell's mission in North America between January and March 1880: it "raised approximately $£ 72,000$, including about $£ 12,000$ for the Land League." But the Irish-born population living in the United States alone is estimated at 1, 615,419 by the end of the $19^{\text {th }}$ century (Alan O'Day, “Irish Nationalism and Anglo-American Relations in the Later 
Nineteenth and Early Twentieth Century", in Fred M. Leventhal \& Roland E. Quinault (eds.), Anglo-American Attitudes: from Revolution to Partnership (Aldershot, Algate, 2000), pp. 174 \& 182). In 1904, M. Davitt judged - probably exaggeratedly and somewhat inaccurately - that a total of $£ 1,200,000$ had been collected abroad over "the past quarter of a century", including $£ 1,002,000$ from the United States, $£ 60,000$ from Australasia, $£ 20,000$ from Great Britain and $£ 12,000$ from Canada (Michael Davitt, The Fall of Feudalism in Ireland, or The Story of the Land League Revolution (London, Harpers \& Brothers, 1904), p. 713).

15. Richard P. Davis, Irish Issues in New Zealand Politics, pp. 105 \&111 \& Rory Sweetman, “Hibernianism in New Zealand, 1869-1969", p. 141.

16. Richard P. Davis, Irish Issues in New Zealand Politics, pp. 124-125 \& 127.

17. Ibid., p. 105.

18. Ibid., p. 126.

19. The quotes are borrowed from Benedict Anderson, "Western Nationalism And Eastern Nationalism”, New Left Review (May-June 2001), p. 42 in https://newleftreview.org/II/9/benedictanderson-western-nationalism-and-eastern-nationalism [17 March 2017]) but B. Anderson coined the phrase "long distance nationalism" a lot earlier in The Spectre of Comparisons: Nationalism, Southeast Asia and the World (London: Verso, 1998).

20. N. Glick Schiller \& G. Fouron, George Woke Up Laughing: Long Distance Nationalism and the Search for Home (Durham: Duke University Press, 2001), p. 4.

21. Inangahua Times, 10 October 1883, p. 2.

22. David Hamer, "Centralisation and Nationalism, 1870-1912", in Keith Sinclair (ed.), Oxford Illustrated History of New Zealand (Auckland \& Oxford, Oxford University Press, 1990), pp. 125-152, in particular 147 \& Keith Sinclair, A History of New Zealand [1959] (London, Penguin, 2000), p. 222.

23. Thomas Mohr, "The Impact of Canadian Confederation in Ireland," in M. Martel, J. Krikorian \& A. Shubert (eds.). Globalizing Confederation - Canada and the World in 1867 (Toronto, University of Toronto Press, 2017), pp. 178-93 \& Conor Neville, "Imperial Precedents in the Home Rule Debates, 1867-1914", MLitt., NUI Maynooth, 2011.

24. New Zealand Tablet, 19 October 1883 p. 21.

25. Te Aroha News, 13 November 1889, p. 2.

26. See for instance Lord Salisbury, "Disintegration. Speeches of the Right Hon. W. E. Forster, M. P., at Devonport and Stonehouse", The Quarterly Review, CLVI, 312 (October 1883), pp. 559-595 \& The Times, 8 October 1885. See also Lionel. P. Curtis, Coercion and Conciliation in Ireland, 1880-1892: A Study in Conservative Unionism, (Princeton, Princeton Books, 1963), p. 427.

27. W. David McIntyre, "Imperialism and Nationalism", in Geoffrey W. Rice (ed.), Oxford History of New Zealand (Auckland \& Oxford, Oxford University Press, 1992), p. 342. See also Keith Sinclair, A Destiny Apart: New Zealand's Search for National Identity (Wellington, Allen \& Unwin in association with Port Nicholson Press, 1986).

28. Otago Witness, 14 November 1895, p. 2.

29. Carla King, Michael Davitt (Dundalk, Dundalgan Press, 1999), p. 60.

30. Otago Witness, 12 December 1906, p. 49.

31. Wellington Evening Post, 2 May 1911, p. 2.

32. John Kendle, Ireland and the Federal Solution, The Debate over the United Kingdom Constitution, 1870-1921 (Montreal, McGill University Press, 1989), pp. 3-4. .

33. Ibid., p. 41.

34. The first Home Rule Bill (1886) initially included the exclusion of Irish MPs of Westminster (Hansard, Parliamentary Debates, 3rd series, vol.304, col. 1055). But the clause raised such protests that Gladstone reverted to the maintenance of Irish MPs in Westminster (The Times, 28 May 1886). The two following Bills stated respectively that 80 and then 42 Irish MPs were to be retained at Wesminster (Ibid., 4th series, vol. 8, col. 1259-62 \& Parliamentary Debates (Commons), 5th series, vol.36, col. 1422).

Revue Française de Civilisation Britannique, XXIV-2 | 2019 
35. John E. Redmond, speech at Cambridge, 27 February 1895, National Library of Oreland, Ms 7,421, p. 21.

36. Michael Davitt, Life and Progress in Australasia (London, Methuen \& Co., 1898), pp. 366, 373-374 \& 393.

37. Interview of R. Hazleton, Wellington Evening Post, 15 July 1911, p. 7 \& Wellington Evening Post, 2 May 1911, p. 2.

38. Letter from William Archer Redmond to John Andrew Millar, quoted in Poverty Bay Herald, 2 August 1911, p. 2.

39. Keith Sinclair, A History of New Zealand, p. 237 \& David Hamer, "Centralisation and Nationalism", pp. 145-6.

40. See Grey River Argus, 15 October 1883, p. 2 \& a speech by the Mayor of Wellington Thomas M. Wilford in New Zealand Truth, 6 May 1911, p. 5.

41. Not all federal imperialists shared this view. Since imperial federation was meant to consolidate the Empire, some believed that Home Rule was likely to lead to a disintegration of the Empire instead of fostering its unity: see Michael Burgess, The British Tradition of Federalism (London, Leicester University Press, 1995), 85-6.

42. Keith Sinclair, Imperial Federation, A Study of New Zealand Policy and Opinion 1880-1914 (University of London, The Athlone Press, 1955), pp. 9, 11 \& 18.

43. "Sympathy with Mr Parnell", Star, 16 March 1889, p. 4.

44. These political figures spoke of imperial federation at seven different Home Rule meetings: two in Wanganui, one in Auckland, one in Wellington, one in Oamaru and one in Dunedin ( Wanganui Herald, 17 October 1889, p. 2 \& 14 November 1889, p. 2; Te Aroha News, 13 November 1889, p. 4; Wellington Evening Post, 16 November 1889, p. 2; North Otago Times, 9 December 1889, p. 2; New Zealand Tablet, 13 December 1889, p. 3)

45. Otago Witness, 12 December 1889, p. 14 \& New Zealand Tablet, 29 November 1889, p. 15; see also Wanganui Chronicle, 14 November 1889, p. 2 \& North Otago Times, 9 December 1889, p. 2.

46. Interest in the issue declined after the collapse of the League in 1893 but was revived again in the 1910s.

47. Keith Sinclair, Imperial Federation, pp. 26-45, especially 26.

48. New Zealand Tablet, 3 January 1907, p. 11. Joseph Ward even announced that "the Government of New Zealand had just concluded a reciprocal treaty with the recently created self-governing colonies in South Africa."

49. Keith Sinclair, Imperial Federation, pp. 14-19.

50. As early as 1880 Justin McCarthy had evoked the possibility for Canada and the Australian colonies to be represented in Westminster but added that it would necessitate a reorganisation of the Empire (Justin McCarthy, "The Common Sense of Home Rule", The Nineteenth Century Review (March 1880), pp. 412-3). Charles Stewart Parnell himself exchanged a few letters on the subject with Cecil Rhodes in which he did not go against the idea of a possible Imperial federation, which Rhodes favoured (see in particular letter to Rhodes, 23 June 1888, in National Library of Ireland, Ms 697, pp. 1, 2 \& 3). Irish envoys to New Zealand also spoke favourably of the idea. Michael Davitt in particular reacted quite positively to rumours that New Zealanders such as Sir George Grey or Sir Patrick Buckley could be provided seats by the Irish parliamentary Party (Interview, New Zealand Tablet, 8 November 1895, p. 13).

51. Wellington Evening Post, 23 May 1911, p. 3.

52. David Hamer, "Centralisation and Nationalism", p. 147.

53. Keith Sinclair, Imperial Federation, pp. 47-48. See also Keith Sinclair, A History of New Zealand, pp. 235 \& 239-40.

Sinclair is one of the historians relied upon in this paper regarding the question of New Zealand and national identity. However it must be noted that his views are not shared by all the scholars 
working on the topic: see for instance James Belich, Paradise Reforged: A History of New Zealanders from the 1880s to the Year 2000 (Auckland, Penguin, 2001).

54. Otago Witness, 12 December 1889, p. 14.

55. “Our Nationality, New Zealand people”, Wellington Evening Post, 8 April 1911, p. 9.

56. Hansard, H. C. Debates, 5th series, vol. 46, col. 2334.

57. In 1886 the census revealed that 300,190 New Zealanders were native-born out a European population of 578,480 . Of these, 256,500 were under the age of 20 and 162,500 under the age of ten (Keith Sinclair, "The beginnings of colonial nationalism: Richard Jebb in New Zealand, 1899", in John Eddy \& Deryck Schreuder (eds.), The Rise of Colonial Nationalism, Australia, New Zealand, Canada and South Africa First Assert Their Nationalities, 1880-1914, Sydney, Allen \& Unwin, 1988, p. 118). In 1901, the New Zealand-born population represented $67 \%$ of a total population of one million (New Zealand Official Year-Book 1902, Government Printer, Wellington, p. 228).

58. Keith Sinclair, "The beginnings of colonial nationalism", p. 119.

59. Keith Sinclair, Imperial Federation, p. 20.

60. New Zealand sent representatives to a convention held in Sydney in 1882, then to the first intercolonial conference that took place in Melbourne in 1890. New Zealand representatives also attended the Sydney National Australasian Convention in March 1891. However, there were no representatives present at the Premiers's Conference in Hobart in 1895 or at the Adelaide Convention in 1897 (Edwin John Tapp \& Miles Fairburn, "New Zealand and Australian Federation", Historical Studies New Zealand and Australia, vol. 5 (1952), pp. 244-257).

61. For a brief historiography of the controversy, see the analysis provided by Ged Martin: "New Zealand and Australian Federation", http://www.gedmartin.net/published-workmainmenu-11/153-australia-new-zealand-and-federation-1883-1901 [5 September 2018].

62. New Zealand refused to join first the Federal Council for Australasia, which was set up in 1883; then the Australian Federation in 1901. The historians that have attributed New Zealand's decision not to join the Australian Federation to a nascent sense of nationalism include Edwin John Tapp \& Miles Fairburn, ("New Zealand and Australian Federation”, pp. 248 \& 256) \& Keith Sinclair (A History of New Zealand, p. 240). Ged Martin is far more circumspect on the subject (see "New Zealand and Australian Federation").

63. Ged Martin, "New Zealand and Australian Federation".

64. See a speech by M. H. R. Joseph Grimmond in the House of Representatives in 1890: "New Zealand should be a country for New Zealanders. With the wings of Great Britain over us we need look to no other country or colony for protection ... we are here the pioneers of a great nation, and shall, no doubt, have a glorious future. ... I think we shall become in every respect a country quite as great as Australia, and with a nationality of our own." (quoted by W. David McIntyre, "Imperialism and Nationalism", p. 342).

65. New Zealand Mail quoted in Bruce Herald, 26 July 1889, p. 4.

66. Wellington Evening Post, 16 October 1883, p. 2.

67. Wanganui Herald, 26 March 1889, p. 2.

68. John Stuart Mill, "Of Nationality, as Connected with Representative Government", chapter XVI of "Considerations on Representative Government", in John Mercel Robson (ed.), Collected Works of John Stuart Mill, vol. XIX, Essays on Politics and Society (London, Routledge \& Kegan Paul, 1977), p. 546. Ernest Renan said the same in his famous conference of 1882: see E. Renan, "Qu'estce qu'une nation", conference given at the Sorbonne, 11 March 1882, in Joël Roman (ed.), Qu'estce qu'une nation? et autres essais politiques, (Paris, Pocket, 1992), p. 54.

69. New Zealand Tablet, 22 November 1895, p. 29.

70. Alan O'Day, “Irish Nationalism and Anglo-American Relations”, art. cit., p. 173. 


\section{ABSTRACTS}

The paper aims to examine the Home Rule question as a debate, which triggered an interest and some discussions beyond the borders of Ireland and the United Kingdom. Through the example of New Zealand, a British settlement colony, which enjoyed self-governance and had welcomed an Irish diaspora, the paper will attempt to shed light on several important facts. First, Irish communities settled abroad were a source of financial and moral support for the Irish Parliamentary Party and for the Irish organisations campaigning for Home Rule for Ireland. Secondly, like Canada or Australia, New Zealand was a colonial precedent, which Irish Home Rulers used to legitimize their demand for self-government. Lastly, the Home Rule issue also allowed New Zealanders to ponder over their own issues, such as their place within the British Empire and their identity.

Cet article étudie l'intérêt et les discussions que la question du Home Rule irlandais a pu susciter au-delà des frontières de l'Irlande ou du Royaume-Uni. A travers l'exemple de la NouvelleZélande, colonie britannique politiquement autonome et qui abritait une diaspora irlandaise, il s'agit de mettre en lumière plusieurs faits importants. Premièrement, les Irlandais émigrés à l'étranger et notamment dans les colonies de peuplement furent une source de soutien financier et moral pour le parti parlementaire irlandais et pour les organisations irlandaises favorables au Home Rule. Deuxièmement, comme le Canada ou l'Australie, la Nouvelle-Zélande servit de précédent que les nationalistes constitutionnels irlandais mirent en avant pour légitimer leur combat en faveur d'une autonomie législative retrouvée. Enfin, la question anglo-irlandaise permit aussi aux Néo-Zélandais de s'interroger davantage sur les problèmes qui les concernaient, notamment leur place au sein de l'Empire et leur identité.

\section{INDEX}

Keywords: Irish Home Rule, New Zealand, imperial federation, transnationalism, Irish diaspora Mots-clés: Home Rule irlandais, Nouvelle-Zélande, fédération impériale, transnationalisme, diaspora irlandaise

\section{AUTHOR}

\section{PAULINE COLLOMBIER-LAKEMAN}

Pauline Collombier-Lakeman is a Maitre de Conférences (lecturer) at the University of Strasbourg, where she teaches nineteenth- and twentieth-century history of the British Isles and English language. After studying at the École Normale Supérieure de Fontenay St Cloud and passing the Agrégation, she was awarded her PhD from the Université Paris 3 - Sorbonne Nouvelle in 2007. Her research work has focused on Irish parliamentary nationalism and on the relationship between Irish Home Rulers and the British Empire. She is the author of The Home Rule Question (1870-1914) published by Belin/CNED in 2018. 
Pauline Collombier-Lakeman est Maître de Conférences à l'Université de Strasbourg, où, outre des cours de langue, elle enseigne l'histoire des Iles britanniques des XIX ${ }^{\mathrm{e}}$ et $\mathrm{XX}^{\mathrm{e}}$ siècles. Après ses études à l'Ecole Normale Supérieure de Fontenay-St Cloud et l'obtention de l'agrégation d'anglais, elle a soutenu une thèse à l'université Paris 3 - Sorbonne Nouvelle en 2007. Ses recherches portent sur le nationalisme parlementaire irlandais, ainsi que sur les relations entre les Home Rulers irlandais et l'empire britannique. Elle est l'auteur de The Home Rule Question (1870-1914) paru chez Belin/CNED en 2018. 